\title{
Is There Any Connection Between Urine Nitrite and Stress Eating?
}

\author{
Muhammad Imran Qadir and Hira Naeem Qureshi* \\ Institute of Molecular Biology and Biotechnology, Bahauddin Zakariya University, Pakistan
}

Submission: May 07, 2019; Published: May 28, 2019

"Corresponding author: Hira Naeem Qureshi, Institute of Molecular Biology and Biotechnology, Bahauddin Zakariya University, Multan, Pakistan

\section{Abstract}

The concentration of nitrite in urine is called urine nitrite. The chemicals nitrates when enter into urinary tract here bacteria convert it into nitrite. In accordance with American Psychological Association the 38\% adults stated that eating of unhealthy foods and overeating are due to tension and stress. The overeating during stress causes the heart disease and diabetes type 2 . The 90 subjects were observed the level of nitrite in urine by urinalysis test. The conclusion indicates that there is no connection between urine nitrite and stress eating.

Keywords: Nitrite; Urine; Nitrate; Urinalysis; Stress eating; Overeating; Heart disease; Diabetes type 2; Chemicals nitrates; Urinary tract; Bacteria; Bad smelling urine; Urine passing; Blood in urine; Ureter; Urethra; Bladder; Kidney

\section{Introduction}

The concentration of nitrite in urine is called urine nitrite. The chemicals nitrates when enter into urinary tract here bacteria convert it into nitrite. The urine nitrite is lead to urinary tract infection and it is commonly occur in females. The symptoms of urine nitrite is bad smelling urine, frequent urge to urination, fatigue, increased of urination, burning with urination, feeling of urination need without much urine passing, blood in urine, painful urination, weakness, fever, reddish and cloudy colored urine. The ureter, urethra, bladder and kidney is effected by nitrite in urine. The nitrite in urine is often leads to kidney failure and sepsis. The sepsis means transfer of infection into blood. The sepsis is lethal and deadly disease. The untreated urinary tract infection are spread approaching to the kidneys [1].

In accordance with American Psychological Association the $38 \%$ adults stated that eating of unhealthy foods and overeating are due to tension and stress. Due to uncomfortable emotions and stress when we are unhappy then we move toward eating that is overeating and leads to obesity. The foods which contained high carbohydrates and fats contents release neurotransmitter named as dopamine in the brain. The dopamine regulate the emotions and movements. The Parkinson's disease is caused by dopamine depletion. The overeating during stress causes the heart disease and diabetes type 2 . The digestive problems, increased blood pressure and raised risk of depression are due to stress eating. The anxiety, sleep disruption and elevated appetite are causes of primary stress hormone named as cortisol [2].

\section{Materials and Methods}

The 90 subjects took part in given research. All subjects were students of Bahauddin Zakariya University, Multan, Pakistan.

The urine nitrite level is check by using urinalysis test. For this purpose first we collected the sample of urine into small container by locating container under urinary discharge. The container should be sterile and unsoiled. Then check level of urine nitrite by performing urinalysis test.

Table 1: Connection between urine nitrite and stress eating

\begin{tabular}{|c|c|c|c|c|}
\hline Gender & \multicolumn{2}{|c|}{ People who have Follower of Stress Eating } & \multicolumn{2}{c|}{ People who have not Follower of Stress Eating } \\
\hline Urine Nitrite & Nitrite Exist in Urine & Nitrite not Exist in Urine & Nitrite Exist in Urine & Nitrite not Exist in Urine \\
\hline Female & $4.22 \%$ & $43.66 \%$ & $0 \%$ & $52.11 \%$ \\
\hline Male & $5.26 \%$ & $63.15 \%$ & $0 \%$ & $31.57 \%$ \\
\hline
\end{tabular}




\section{Result and Discussion}

The connection between urine nitrite and stress eating is specified in Table 1. The Parkinson's disease is caused by dopamine depletion. The overeating during stress causes the heart disease and diabetes type 2 . The $4.22 \%$ female and $5.26 \%$ male have nitrite in urine while $43.66 \%$ female and $63.15 \%$ male have absent of nitrite in urine says that they have addict of more eating during stress. The $0 \%$ female and $0 \%$ male have nitrite in urine while $52.11 \%$ female and $31.57 \%$ male have absent of nitrite in urine says that they all have not addict of more eating during stress [3-10].

\section{Conclusion}

There is no connection between urine protein and stress eating.

\section{References}

1. Lee S, Son SC, Han MJ, Kim WJ, Kim SH, et al. (2008) Increased intestinal macromolecular permeability and urine nitrite excretion associated with liver cirrhosis with ascites. World J Gastroenterol 14(24): 38843890.
2. Torres SJ, Nowson CA (2007) Relationship between stress, eating behavior, and obesity. Nutrition 23(11-12): 887-894.

3. Qadir MI, Javid A (2018) Awareness about Crohn's Disease in biotechnology students. Glo Adv Res J Med Medical Sci 7(3): 62-64.

4. Qadir MI, Saleem A (2018) Awareness about ischemic heart disease in university biotechnology students. Glo Adv Res J Med Medical Sci 7(3): 59-61.

5. Qadir MI, Ishfaq S (2018) Awareness about hypertension in biology students. Int J Mod Pharma Res 7(2): 8-10.

6. Qadir MI, Mehwish (2018) Awareness about psoriasis disease. Int J Mod Pharma Res 7(2): 17-18.

7. Qadir MI, Shahzad R (2018) Awareness about obesity in postgraduate students of biotechnology. Int J Mod Pharma Res 7(2): 14-16.

8. Qadir MI, Rizvi M (2018) Awareness about thalassemia in post graduate students. MOJ Lymphology \& Phlebology 2(1): 14-16.

9. Qadir MI, Ghalia BA (2018) Awareness survey about colorectal cancer in students of M. Phil Biotechnology at Bahauddin Zakariya University, Multan, Pakistan. Nov Appro in Can Study 1(3).

10. Qadir MI, Saba G (2018) Awareness about intestinal cancer in university student. Nov Appro in Can Study 1(3).

\section{Your next submission with JuniperPublishers will reach you the below assets}

- Quality Editorial service

- Swift Peer Review

- Reprints availability

- E-prints Service

- Manuscript Podcast for convenient understanding

- Global attainment for your research

- Manuscript accessibility in different formats

( Pdf, E-pub, Full Text, audio)

- Unceasing customer service

Track the below URL for one-step submission

https://juniperpublishers.com/online-submission.php 